\title{
UK managers' conceptions of employee training and development
}

\section{Short title: Conceptions of training and development}

\begin{abstract}
Purpose: Firstly to review the practical and theoretical distinctions between training and development in the organisational psychology and HRD literatures. Secondly to investigate how managers responsible for the training and development function conceptualise these activities in practice, the factors which guide their decision making, how they evaluate the outcomes and the extent they perceive a relationship between training and development.
\end{abstract}

Design/methodology/approach: Taking a critical realist perspective 26 interviews with UK managers were conducted and analysed through thematic coding using Template Analysis.

Findings: Managers conceptualisations of training and development vary. Formal training is prioritised due to a perceived more tangible demonstrable return on investment. Perceived success in training focuses on improvements to job related skills whereas success outcomes for development are more varied and difficult to measure. Managers consider training and development more valuable when combined.

Implications for research: There is a need for further process driven research to understand the interrelationship between training and development and to develop methods that can be used by organisations to evaluate both. This necessitates going beyond methods currently in use and include both qualitative and quantitative measures. 
Implications for practice: Managers may take a more proactive and directive role in facilitating development than the literature suggests, consequently their role needs to be more actively considered in HRD learning strategies.

Originality/value: This is one of the first qualitative studies to explore the conceptualisations of managers responsible for training and development, highlighting the interrelationship between training and development and the factors guiding decisions regarding these activities.

Key words: training, development, managers, decision making, evaluation of success, Template Analysis.

Categorization: research paper. 


\section{UK managers' conceptions of employee training and development}

\section{Introduction}

There has long been a belief that investment in employee training and development has benefits for the organisation and for its workforce (Salas and Cannon-Bowers 2001; Sloman, 2003), some form of training being offered by nearly all organisations (Cannell, 2004). However, with the move from traditional formal training activities to on-going and future-oriented development there has been a shift in how such activities are used (e.g. Maurer et al., 2003). A continuously changing work environment has made cyclical training necessary (Buckley and Caple, 2007), on-the-job training being considered most effective, only a fifth of UK managers believing that formal courses are the most effective method (Chartered Institute of Personnel and Development, 2007). Self-initiated training and development, initiated by the learner, has also increased in importance, particularly in the context of so-called 'new' or 'boundaryless careers' (Arthur and Rousseau 1996) characterised by greater mobility and flexibility. In-house development programmes are offered by $60 \%$ of UK organisations (Chartered Institute of Personnel and Development 2007). The same research showed that one in six organisations has introduced programmes specifically aimed at developing the role of the line manager, which demonstrates their crucial role in this context. For this reason, managers with responsibility for these activities are the focus of the present research as they act as gate keepers to training and development in many organisations, thereby playing a pivotal role in decisions regarding such activities.

The aims of our paper are thus two-fold. Firstly to review and provide clarity on both the practical and theoretical distinctions between training and development drawing from the organisational psychological and HRD literatures; and secondly to investigate how managers conceptualize these activities in practice, the factors which 
guide their decision making, how they evaluate the outcomes of these activities, and the extent they perceive a relationship between training and development.

\section{Differences between training and development}

Not all writers agree regarding the overall aim or the potential differences between training and development. Antonacopolou (2001) conceptualises training as an organisational activity, which also comprises development, contrasting this with learning as an individual activity, thereby making a distinction between organisational and individual learning. However, we argue that we need to make a more finely grained distinction. Training and development are in format and purpose distinct activities, for instance Warr (2002, p 154) argues that "job-specific training seeks to improve effectiveness in a current job role, whereas development activities take a longer-term perspective and may extend into career planning and reviews of personal progress". Such distinctions are also apparent in the North American literature. Laird (1985, p.11) writes that training "permits employees to perform to a standard whilst development on the other hand refers to ongoing, long-term intervention to prepare people and groups for futures", whilst Maurer et al. (2002b) distinguish development activity by locating the onus for development firmly with the employees themselves, but considering different beneficiaries. Thus, within the literature training and development appear different (Table 1). Practical differences emphasise how training is a focused and time-framed activity with clear organisational focus whilst development is open-ended and long-term; the role of managerial support being important for each activity. Evidence from a practitioner context (Chartered Institute of Personnel and Development, 2007) emphasises that $52 \%$ of respondents see the manager as 'very important' for supporting learning for both training and development activities, a finding also echoed in the academic literature particularly in terms of participation in development activities (Birdi et al., 1997). However, it is less evident how decisions are made regarding which of these activities to support. Examples of training tend to comprise formal activities that usually entail a specific skill building element (Goldstein and Gilliam, 1994), whereas development comprises a very broad range of activities, which can be formal or informal (McDowall and 
Mabey, 2008), may or may not entail an explicit career relevant element and may or may not be formally planned and agreed (Rowold and Kauffeld, 2009).

[Note to editor: Take in Table 1 about here]

Approaches to training tend to be grounded in the training cycle. Developed from learning theory and cognitive psychology these acknowledge the interplay between individual characteristics (Goldstein, 1993) focussing upon training effectiveness (e.g. Kraiger et al., 1993) and factors impacting upon motivation (Colquitt et al., 2000). Warr (2002, p.154) states that "Learning [from training] may be viewed as cognitive and physical activity giving rise to a relatively permanent change in knowledge, skill or attitude", such outcomes have been documented in a wealth of studies (Kraiger et al., 1993) and several meta-analyses (Arthur et al., 2003). Consequently research has often concentrated on individuals' motivation for training and the impact of a range of variables such as self efficacy (Colquitt et al., 2000).

In contrast there is far less research, particularly in psychology, regarding employee development (Maurer et al,; 2002a) and less consensus on definitions and a theoretical basis. The theoretical roots for development are equally widely spread. Several of these are positioned at the organisational level; examples are Human Resource Development orientated approaches (Thomson et al., 1998), the learning organisation (Senge, 2006) or Human Capital Theory (Davenport, 1999), a commonality between these models being that outcomes are often concerned with the enhancement of performance. Other development approaches consider individual differences and motivation such as theories of managerial competence (Boyatzis 1982; 2008), the effects of feedback (Ilgen et al., 1979; Kluger and DeNisi 1996) and factors influencing participation in development activities ( Maurer et al. 2002b; 2003; Maurer and Tarulli, 1994).

With regard to learning arising from any such activity, it is implicit across these theories that individuals will develop more effectively if they are cognisant of their 
strengths and weaknesses, and thus take responsibility for changing their behaviour if supported by appropriate development activities. Unlike for training, where learning is characterised as occurring through instruction and skill acquisition (Goldstein and Gilliam, 1994), learning through development is characterised by reflection. To illustrate, Argyris and Schön (1978) argue that individuals need to examine their implicit theories (theories-in-use) in comparison to espoused theories (how they want to be seen to be acting by others). The better the fit between the two theories, the greater their effectiveness, reflection being integral to achieving this fit. In order for such self-reflection to take place, employees need insight into their respective strengths and weaknesses and to be able to see themselves in the same way as others do. Such self-awareness has been has been demonstrated to predict performance (Atwater and Yammarino, 1992).

At this point we note that the psychological distinction between both the processes of training and development, and learning, the latter of which can be conceptualised as an outcome (Warr, 2002), differs from much contemporary management literature. This considers development as synonymous with learning (e.g. Sadler-Smith, 2005; Harrison, 2005). Notwithstanding this, learning from each type of activity might broadly be argued to be contingent on differing employee-employer relationships (Horner and Jones, 2003). Training is associated commonly with relational aspects of the psychological contract (Rousseau, 1995), which infer stable and open-ended employment within a predictivist perspective centring on the prediction of job related performance, within a very quantitative paradigm (Cook, 2009). Within this, the onus rests with the manager to match people to jobs and then to train their workforce, facilitating skill acquisition and linear career growth. In contrast, development is more commonly associated with transactional contracts (Rousseau, 1995) and a constructivist perspective, where the onus is on the employee to take responsibility for developing multiple careers and engaging in life-long learning (Senge, 2006; Hall and Mirvis, 1995).

These differences offer challenges for evaluating training and development outcomes. Training lends itself to experimental designs to assess projected outcomes, often 
based upon Kirkpatrick's (1959) model of training evaluation or derivatives, that demonstrate effectiveness at several levels such as increased learning, increased motivation and enhanced attitudes (Tannenbaum et al., 1991). Despite criticism in the literature (Skinner, 2004), such evaluation models are popular with managers (Tamkin et al., 2002) due to their summative and outcome focused orientation (Brown and Gerhard, 2002). Phillip's (2003) Return on Investment model expands on Kirkpatrick through a proposed framework for measuring return on investment using primarily quantitative methods, noting the relative reluctance of organisations to evaluate development in comparison to training.

On-going development activities are less suited to such experimental evaluation. Development is by nature pervasive, overlapping and on-going, making it more difficult to divide up relevant activities into discrete variables (Warr, 2002). The notion that development should be self-led implies it is a personal issue.

Consequently what constitutes successful development for one person might not represent success for another. Whereas some employees might wish to stay in their existing job and find satisfaction through the enhancement of their job specific skills, others define successful development as promotion and increased pay. Thus, prevalent outcome measures have been general and posited at the organisational level such as the number of training days attended by managers (Thomson et al., 1998), promotions (Jones and Whitmore, 1995) or staff retention (Naish and Birdi, 2001). These issues highlight a need to explore how individuals responsible for training and development in organisations conceptualise development in practice; how decisions to invest are made, outcome success measured and effectiveness judged. Whilst we know from the training effectiveness literature that motivation predicts training success (see Colquitt et al., 2000), we lack comparable evidence for employee development.

To summarise, our review highlights that training and development are conceptualised as different by researchers (Warr, 2002; Laird, 1985; Fitzgerald, 1992). However, there is little research regarding the extent to which these differences are endorsed and shared by people in organisations. For instance, there may be a limit to the extent development can truly be self-led; engagement arguably being dependent on the 
allocation of budgets, unless employees self-finance such activities in their own time. Managers with relevant responsibility can play a vital role in employees' training and development where they identify needs and allocate resources, as well as accept personal responsibility to encourage employees to participate in activities and support them to transfer developed skills (Reid and Barrington, 1994). Survey evidence suggests these managers are considered 'very important' to supporting both training and development activities in organisations (Chartered Institute of Personnel and Development, 2007), although a fifth of respondents also indicated that managers may not take this issue seriously. Given that a recent survey of training managers in the UK commissioned by the Confederation of British Industry [CBI] revealed that few expected their budgets to remain unaffected by the recession, the majority having already experienced budget cuts (Kingston, 2009), this decrease in funding lends urgency to investigating how needs are identified and resources allocated.

Consequently we took a qualitative approach rooted in critical realism (Willig, 2001). Whilst our methods were qualitative, our starting point was the above review of the literature, which revealed that theories as espoused by the literature may not necessarily be reflected in organisational practice. A realist stance takes the position that qualitative approaches can uncover shared perceptions of reality, and thus if research is conducted with integrity, allow generalisations to other populations. A critical realist perspective goes one step further by using the interpretation of data to subsequently question and revise theories that have guided the research. We interviewed managers to investigate their conceptualisations of training and development, with particular focus on the factors guiding decision making, and how success is evaluated in their organisational realities. To this end, our research questions are:

1. How do managers define and conceptualise development and training in practice?

2. What factors guide managers' training and development decisions?

3. How do managers evaluate outcomes for training and development?

4. To what extent do managers perceive a relationship between training and development? 
Whilst some evidence has been extant that underlines the importance of the role of the manager responsible for such decisions, to our knowledge no qualitative study has not investigated in the UK context what managers' perceptions are, and in particular what guides their decision making.

\section{Method}

\section{Sample and recruitment procedure}

As our aim was to investigate the above research questions in depth through a qualitative approach, rather than survey a statistically representative population, we recruited a purposive sample (Silverman, 2000) of 26 managers (16 male, 10 female, aged between 28 and 59) from 20 different UK organisations. These were drawn from a UK database, and we ensured that our sample comprised both the public sector (local authorities, the emergency services, education) and different private sector industry sectors (including finance, retail and publishing). The organisations were contacted via an invitation letter or email outlining the purposes of our research and inviting participants who fitted our inclusion criteria to put themselves forward. These were that managers had responsibility for identifying development and training needs in employees, were making decisions on taking appropriate action (such as recommending attendance of a particular course or activity following a staff appraisal) and had been making such decisions for a period exceeding six months. The nature of managerial responsibilities in our final sample varied from senior managers (with active line management for up to 50 staff) to those with responsibility for specialist training and development functions. It was ascertained at the outset of each interview that these criteria were met, and that managers had relevant authority such as being able to agree budgets. The sample was sought to represent a range of contemporary experiences of those employees critical (Patton, 2002) to managing training and development. All managers were sent a short information sheet outlining the nature of the research in advance via email. The interviews were conducted during work-time by telephone, thereby allowing participants to be recruited from geographically dispersed locations, at a mutually agreed time in order to ensure minimal disruption. As the interviews were not face to face, particular care was taken at the beginning of 
each interview to corroborate the inclusion criteria for each participant, but also to allow time for questions on part of the interviewee to ensure good rapport. Inevitably this was made difficult by the absence of non-verbal cues offered by face-tot-face interviews (Dillman, 2009). Each interview was recorded once informed consent had been obtained and, subsequently, transcribed fully. All participants were assured that their own identities and that of their organisations would be anonymised, and received a summary of the findings upon request. We refer to participants as ' $\mathrm{A}$ ', 'B', ' $\mathrm{C}$; in the results section and have, to preserve anonymity, also disguised the identity of each organisation.

\section{Interview schedule}

Interviews lasted approximately 45 minutes and consisted of semi-structured, openended questions with follow up probes focussing on managers' definitions and experiences in their work contexts. The interview schedule was constructed to map onto our research questions; thus the broad headings were definitions of training and development, decision making, examples of outcome measures, and the interrelationship between training and development. When asking managers to render their own definitions of training and development, and to indicate which activities they would consider pertaining to each (if this distinction was meaningful) a question pertaining to decision making was "Under what circumstances or conditions are [particular type of activity] most useful?" A subsequent probe was "What would make you choose development rather than training activities, for a particular employee?" A full schedule is available from the first author on request.

The schedule was piloted with an opportunity sample of five managers; who commented that our questions were clearly phrased and relevant. Despite this, whilst conducting the first six interviews, it became apparent that participants found it much easier to define and talk about training than development, these managers having to be prompted on the latter. Subsequently the schedule was amended so participants were first asked and probed about development first in order to make this concept more salient. All interviews were transcribed verbatim, retaining idiosyncratic expressions and grammar. Following Poland's (2002) recommendations, words that were 
emphasised in the conversation are capitalised, pauses in the text are indicated with (...); and, where participants were citing others, this was indicated with single parentheses.

\section{Template Analysis}

The transcripts were analysed using Template Analysis [TA] (King, 2004) to code the data. Data were analysed from a realist perspective, thereby enabling the initial coding phase to be guided by the research questions. The defining feature of TA is that a set of meaningful themes (first level codes that are applied throughout the data and interpreted as being relevant to the research questions) and codes (labels that are attached to the data) are applied to parts of the data set and revised as necessary. This facilitates a holistic approach, rather than considering one theme or code at a time.

Adopting King's (2004) guidelines, coding was undertaken in a hierarchical manner, using the meaningful themes to encompass successively narrower and more specific second and third level codes. Whilst there is little guidance about determining nonprobabilistic sample sizes, work by Guest et al. (2006) demonstrated that basic elements (meaningful themes or first level codes) can typically be identified after analyzing approximately six interviews; this number also formed the basis of our initial analysis. Our preliminary template showed that managers differentiated conceptually between training and development, since more differences than links or overlap appeared. We subsequently used this template to analyse all remaining transcripts through a process of constant revision: Definitions were refined, new codes added and redundant codes removed, more salient themes being moved to higher level codes and less salient themes to lower level codes as the analysis progressed. This process continued until no new codes emerged from the data. Although relatively few alterations to the template were made after 13 interviews had been coded, we reached 'saturation' (Patton, 2002) when 19 interviews were analysed in full, the analysis of the remaining seven interviews also resulting in no additional changes to the coding. Throughout this process, we debated the codes used as a reflective process to ensure that coding was rooted in the data, rather than influenced by our individual biases and assumptions. 
In line with Brown and Clarke (2006) the emphasis of our analysis was on meaningful coding and making links between the interpretations of the themes, rather than reducing the data to frequencies. This is illustrated in Table 2 where, for the first level theme, 'Links between training and development', respective second level codes were 'Intertwined functionality' defined as 'training and development are commonly administered by the same functions' and 'Combined effectiveness', defined as 'the two activities are considered to work better if used in tandem'. Third level codes summarised these themes in more detail.

[Note to Editor: Insert Table 2 about here]

The final Template comprised seven first level (meaningful) themes which we outline and use to structure the findings discussed below. These are integrated with quotes from participants; selected as they are particularly pertinent illustrations of particular points made. Whilst the focus of our analysis was across participants, to elicit shared themes, we also highlight where we encountered differing perspectives.

\section{Findings}

Our first section, Conceptualisations of training and development discusses the meaningful themes 'definitions of training and development', 'differences between training and development' and the 'process of learning in training and in development' to address our first research question. The second and third sections map directly onto the themes 'Training and development decisions' and, 'Evaluation of outcomes', and our second and third research questions. Our last section, the relationship between training and development, considers our final research question using the themes 'links between training and development' and 'success factors'. 


\section{Conceptualisations of training and development}

All participants viewed development as broader than training, focussing upon the person rather than the job. Participant A, a middle manager from the emergency services summarised this: "I think development is for ME (...) I think training as one for the JOB." Training was about the provision of courses to meet specific needs, whereas development was perceived as long-term, and occurred as part of individuals' progress in their job. A typical quote from Participant B, a senior manager in the media industry, was: “(...) training I would describe as a specific programme to address specific needs, development I would describe ultimately as the sort of longterm change in an individual as they work towards a specific target." About a third of managers considered that development went beyond the current job and linked with employees' personal life, whereas training always remained confined to the job. Two managers, Participant $\mathrm{D}$ from the private sector and Participant $\mathrm{E}$ from the public sector, used the example of learning how to drive a car. Each likened training to the initial learning to drive process, and development to taking an advanced driver course, in which acquired skills were honed and practiced to a deeper level:

"As an example, I suppose driver training you need to learn how to drive the car and that's your training but then you go onto develop those skills further to become an advanced driver" (Participant D).

Training was seen by about a quarter of managers as a means for development; in other words training was a process and one available mechanism to support an individual's development, development being the outcome and an umbrella term. Participant B commented: "Training I would see as something that FEEDS into development, I would not say that they are different (...) ultimately, training feeds into long-term development." This suggests a link between training and development, as explained by a Participant F, a senior manager from the private sector:

"Development I would see as something that is a sort of on-going development, many things feed into development. One of the things that may feed into development is training. I see training as a specific thing that is done to address either a specific need or a long-term need. Whereas development is something that can be down to a person's day-to-day job, which ultimately 
should be developing them, if that makes sense. Training I would describe as a specific programme to address specific needs, development I would describe ultimately as the sort of long-term change in an individual as they work towards a specific target."

Despite general agreement that development and training were linked, managers differentiated between them according to the practical aspects. Training was seen as skills-based, technical and focused on the current job, whereas development was seen as wider-ranging and relating to interpersonal skills; mirroring the definitions of Warr (2002) and Laird (1985) considered earlier. There was agreement that training was always planned and formal whereas development activities could, in addition, be adhoc, unplanned, sporadic and informal. In approximately half of interviews, development entailed a career-related element focussing upon a change in the person's duties, such as a move into a different job role, department or a promotion. In contrast, training referred to the present, was considered to be confined to a particular time period and had a distinct beginning and end; development was directed to the future, remained on-going and was open-ended.

Training was provided by the organisation through internal or external training courses, which were either generic or tailored to specific requirements. Participants noted several ways for providing development. The majority highlighted how it could be provided or initiated by the line manager, whilst nearly half cited a collaborative approach that built on two-way communication. This approach to development was explained by Participant G, a manager for an IT team in the financial industry as “... and the ones that come out as being most successful are a need that's been identified by the individual as well as by the manager, rather than just the manager has decided "you need this"”. This suggests that whilst the motivation for development has to come from the individual, and is in line with the paradigm of new careers (Arthur and Rousseau, 1996), development may not necessarily be as self led as implied by the literature; with some managers playing a pivotal role. This has implications for practice which we will return to in our discussion, as given the 
importance of such managers for decision making processes, it is necessary to ensure that this is actively considered in the overall organisational strategy.

Managers were asked directly which activities they perceived as pertaining to training, and which ones to development. Whilst there was clear agreement regarding most activities, such as formal courses being training, and shadowing or secondments being development, there was also some dissonance. Some aspects of their responses contradicted classifications prevalent in the literature (Mauer and Tarulli, 1994; Maurer et al., 2003). In particular, approximately a third of managers argued that in their organisations the distinction was based on content; automatically labelling any activity concerned with discrete skill improvement as training and any activity to do with 'soft' (people) skills as development. Others (a quarter) differentiated by degree of structure, arguing that, for instance, staff appraisals or 360 degree feedback were considered training rather than development, due to their high degree of structure and pre-planning. This indicates training and development activities are perhaps not as clearly differentiated by managers as the literature suggests, and that individual perceptions may be organisation dependent.

\section{Training and development decisions}

Decisions to support training or development appeared contingent on employees' level in relation to their job. Where employees were lacking key skills, they received training to equip them to perform in their current job. Once an employee had been trained and the focus was outside her or his current job role, development activities were considered more appropriate. Activity choice appeared dependant on the nature of objectives set. For clear and measurable objectives (such as gaining specific technical skills) training was chosen, whereas if objectives were more widely focussed such as needing to learn about a different area of the business, development (often involving shadowing or mentoring) was considered more appropriate.

Participant $\mathrm{H}$, a manager from an educational environment summarized the decision as:

"I think they're different. I think for training it's a question of having the skills and the knowledge to do the job that they're doing now and making sure that 
performance is at a reasonable level.....once they've got their tool-bag fairly healthily full up with the training they need to do, then I would consider developmental training, on secondments and things like that".

Over half the participants, and in particular those with specialist responsibility for training and development, argued that when making decisions, training usually took precedence over development since training had demonstrable benefits to the organisation that were more easily quantifiable. The preference for training was illustrated by Participant I, a manager from the services industry who commented:

"I think the actual training course would always take precedence over maybe a more esoteric development course (...). If you're spending money on training then there's GOT to be some demonstrable return for the company to make that investment. That there are going to be demonstrable benefits coming back to the company for spending that money".

Such preferences for training were, in general linked to organisational requirements to address skill shortages, as a matter of priority; resulting in development activities being given less priority, Participant I continuing:

"If it was something that, a change, a person literally couldn't perform their job without going, quite often that will happen as well, the legislative changes and that kind of thing. So basically I think that training sometimes would come out as the higher priority, if there was a need of that kind, so if there was very poor performance I think training would have to. So I think (...) development can sometimes be secondary".

Participant $\mathrm{J}$, a senior manager from the finance industry however disagreed with the apparent precedence given to training commenting that a focus on more interpersonal aspects, taking a 'coaching approach', was considerably more valuable to his organisation:

"I think it varies a lot; it really depends on the individual and the circumstances. My own view is that coaching and that sort of personal one-onone development is more useful than standard courses. Sometimes you just have to do standard courses but very often the outcomes of spending one-onone time with someone, or one-on-two, or whatever it is, as long as they are 
prepared to do it are far more useful, a much better use of our time and our money".

Despite this expressed preference for more informal, one-to-one discussions with employees, this manager's view was qualified by “... as long as they are prepared to do it". Similar comments from other participants in relation to development support research regarding the importance of employees' motivation as a prerequisite for successful training outcomes (Colquitt et al., 2000). In summary preference was usually given to training due to its demonstrable benefits, in particular with regard to addressing skill shortages. The requirement of demonstrable benefits was also important in development decisions. However individual motivation appeared more crucial for development than training decisions. In this then, there is a potential paradox that needs to be addressed which has implications for practice. On the one hand, managers in this sample played an active role, but on the other hand expected a level of motivation from employees for any activity to be supported. In order to be fair and transparent and promote organisational justice, it would be important to make this explicit and transparent from the outset in negotiation and consultation with employees, so that they knew what was expected.

\section{Evaluation of outcomes}

In line with our findings relating to definitions and decisions, there was agreement from all participants that evaluation of training outcomes focussed upon improvements to specific job-related skills. As suggested by the literature (Skinner, 2004) these included observable behaviour changes subsequent to the training, which would be later transferred to the job. These were considered straight-forward to measure, visible and linked to clear objectives. In contrast, development outcomes were considered to be more varied, and likely to extend over a longer time period. Consequently, they would not be immediately visible following engagement in an activity. Participant K, A public sector manager summarised this in a typical response:

“(...) less easily measured, of a longer-term nature, in other words you don't go to another course to develop your interpersonal skills and come back with them 
wonderfully developed. It's something that you build up and develop over a period of time I think".

Development outcomes were considered private to the individual by most participants, coaching for example being highlighted as a confidential process, rendering any outcomes less tangible, open to interpretation and difficult to measure. As suggested in the literature (McDowall and Mabey, 2008) the majority of participants perceived development outcomes as future-directed and open-ended. As a result, they were considered potentially difficult to evaluate longitudinally; individuals' insights into their strengths and weaknesses, and therefore their personal goals, being likely to alter during a development process. Participant J offered an illustration that typified comments made by several participants, highlighting how goals might alter during the development process:

“...and I think it's quite difficult to do even longitudinally because you could ask somebody at the beginning of something 'how do you feel about such and such' and they might say 'well I feel OK' but then having gone through the process and seeing themselves develop, they say 'well I didn't even', sometimes people don't even know realise what their gaps are until they try something. (...) If you think about the evaluation of development I think it's got to be more qualitative (...) it's got to be more subjective, because that's the very nature of development it's the person who takes from the opportunity what they need".

This observation from one of our participants concurs with our earlier discussion drawing on Warr (2002), that experimental evaluation studies prevalent in the training literature are difficult, if not inappropriate, to apply to the evaluation of development activities, as due to their long-term nature the parameters can be subject to constant change.

\section{Relationship between training and development}

As highlighted in our earlier discussion of definitions, managers argued that combining training with development resulted in more positive outcomes. Participant L, a services manager with responsibility for training illustrated this, outlining how 
her organisation had achieved great success where an under-performing employee who underwent specific external training course, which was accompanied by coaching from a more experienced co-worker, helping her to embed the learning in the workplace: "You know, this really made the difference. Following things up, talking it through, and getting a helping hand from someone more experienced". This illustration, typical of those offered by the majority of participants, indicated how behaviour change resulting from training might be transferred more successfully if supported through development activities and support in the immediate work environment. Such activities were argued to create, or at least contribute to, a more conducive transfer climate; a factor which the training literature has identified as particularly important for success (Rouiller and Goldstein, 1993: Tracey et al., 2001).

The matching of training to recipients' needs and abilities was highlighted as a contributory factor to training success by the majority of participants. Effective trainers who related to their audience, along with provision of practical on the job applications and the resulting transfer of learning, were considered crucial; this being congruent with Kirkpatrick's model (1959) and its derivatives. In contrast, for development, managers argued that success was linked to individuals' motivation, their 'buy in' to the process, their openness about what needed to be changed, and willingness to stretch themselves "out of their comfort zone". This was typified by a Participant M, a public sector manager, who commented: "I think with development you are going to get nothing unless the person is really open to taking, to seizing an opportunity".

\section{Discussion}

Findings from our data are, to some extent, consistent with the literature reviewed earlier in that they confirm training and development are perceived as different. However participants also argued that some activities were not easily distinguished, for instance when training encompasses a long-term developmental element, or conversely where activities seen typically as development, are structured and traininglike in format. Different foci for training and development appeared to guide 
managers' decision making. Where an employee needed job specific skills, or was under-performing in their current job, training was preferred. Where employees were ready to move beyond the current role, or where there was a need to enhance interpersonal skills, development activities, such as secondments or coaching, were favoured.

Our participants provided additional insights regarding the impact of linking training and development activities, the role of managers in encouraging and supporting individuals' training and development, the influence of measurable return on investment in decision making and the importance of employee motivation as a prerequisite for development success. It is to these (summarized in Table 3) that we now turn.

[Note to Editor: Insert Table 3 about here]

Managers with responsibility for training and development decisions perceived training and development as interlinked, training being one of the mechanisms that could lead to and support development. Participants highlighted how specific training was perceived to be more effective when undertaken in conjunction with individual coaching that supported the transfer of learning back into the work place. This we interpreted as a dominant theme in the analysis that 'training feeds into development'.

Building on this, a minority of managers interviewed felt directly responsible for individuals' development as well as their training; commenting that this was something they actively provide for their staff. This indicates that, from a managerial point of view, it may be unrealistic to assume that development activities are as selfled as the literature would advocate (e.g. Hall, 1996). Whilst these managers described their role in relation to training as meeting established business needs, this was rarely the case with regard to development. Rather they considered their role was to encourage and nurture those employees who were prepared to commit to their own development. 
Our findings highlighted, managers' perceived the lack of demonstrable return on such investment as a potential barrier for employees' engaging in a number of wideranging development activities. In apparent contrast to evidence in the UK (Chartered Institute of Personnel and Development, 2007), managers with an HR role favoured training over development, the latter's outcomes being construed as less clear. Managers considered training outcomes were visible and quantifiable; and could be measured through improvements such as skill levels on the job. In contrast development outcomes were felt to be largely subjective, private to the individual and not necessarily linked to specific objectives. Where managers were unable to quantify a development activity's value, they were less likely to support it, or allocate resources. From the managers' perspective, employees' motivation to develop and their willingness to stretch themselves beyond what they were currently doing and to move out of their comfort zone, were important pre-requisites for success of development activities. In contrast to training, where the impetus came from the organisation, managers considered the impetus for development should come from the individual. Within this, they recognised that learning was likely to occur at least in part through interaction with and support from others.

\section{Implications for research}

Whilst our findings highlight the interrelationship between training and development, and for some managers an associated developmental role, further research is required to explore this. Although some research has indicated that combining activities appears to be related to successful outcomes; for instance 360 degree feedback appears to result in slightly more effective goal setting and execution if followed up by executive coaching (Smither et al., 2005), this is limited. In particular there is therefore a need for process driven research that adopts a formative perspective exploring how combining training and development activities further learning. Adopting a mixed methods approach to provide quantitative measures and inform understanding such research could consider whether specific training activities are best followed by particular development processes, and the conditions under which 
particular combinations are successful. Training and development activities do not happen in isolation in organisations, and such research needs to acknowledge this complexity.

Explicit within our research findings is the need to develop methods of evaluation that not only encompass training but also subsequent broader development activities. These should consider different perspectives, to elucidate the impact of the individual, her or his manager, the HR professional responsible for training and development and contextual factors have on learning. One way of achieving this might be through formative evaluations (Brown and Gerhardt, 2002). Relevant case studies from the literature might subsequently aid practitioners to develop bespoke evaluation techniques that go beyond those currently in use (Skinner, 2004). Whilst writers such as Boudreau and Ramstad (1998) argue the need to place emphasis on linked processes, we postulate that psychological approaches also have value to add by helping us to understand 'soft intangible factors' such as individual differences. Our research suggests that quantitative approaches to evaluating development are likely to be incomplete or even misleading, as envisaged goals and outcomes (e.g. a promotion; or a potential career change) are likely to alter during the process being at least partially dependent on factors outside the individual's control. There is therefore a need to further understanding of how development outcomes can be measured and evaluated at the individual level, traditional experimental designs and related measures being perhaps too narrow and short-term in focus to capture the richness and time-span involved.

To date limited research has concerned itself with the longitudinal aspects of personal development plans despite by nature there being working documents that are subject to constant revision and change. This renders long-term evaluation difficult. A thorough investigation of such development plans may help us to understand what makes them effective, alongside what and how much support from the manager and other involved stakeholders is expected, and ultimately is useful. Whilst the managers we interviewed felt that it was up to the individual to take responsibility for development, they also highlighted the importance of their support for employees to engage in these activities. Research therefore needs to explore the roles such 
managers play in development, how these can be best facilitated, and the potential pitfalls. Approaches such as the Change Paradigm originally applied in the context of evaluating therapeutic interventions, to determine affective change events in this context (Rice and Greenberg, 1984), might usefully be adapted to facilitate our understanding of at what point and under what conditions development is facilitated in discussions between manager and employee.

\section{Implications for practice}

Differences between managers and researchers in their conceptualisations of training and development suggest potential difficulties in research findings being translated into practice due, not least, to alternative understandings. Whilst this factor has already been recognised in the literature on the relevance of management research (e.g. Cohen, 2007), it provides further evidence of potential barriers to ensuring practice implications are recognised as such by practitioners. Notwithstanding this issue, we consider the research outlined has important implications for practice.

Within organisations the potential for differences between HR managers' and line managers' implicit theories regarding the relative value of training and development suggest the possibility of conflicting advice and less than optimal results. If training and development are to be effective both groups need to understand the purpose and agree their value to the organisation. The results also showed that managers may have quite different understandings of development processes, as a) they seem to take a more involved role than the literature suggests and b) expect a great deal of motivation demonstrated on part of the employee for them to consider development further. There are several implications arising from this. First, the role of the managers responsible for individuals' training and development decisions needs to be actively considered in an overall training and development strategy, as they appear to have a key role in fostering a good learning climate. Secondly, it is important that any expectations are made explicit and transparent, thereby adhering to principles of organisational justice. This will allow employees to play a role, to be more committed and more satisfied with the process (McDowall and Fletcher, 2004). Lastly, the differences in perceptions highlight another implication, which is the need to 
demonstrate the value of both training and development activities to the organisation. Whilst we have already alluded to this in our discussion of implications for research, there is a need for practical relevant evaluation techniques that encompass both training and development activities.

Such new evaluation techniques need to take into account another practice implication of this research; that training appears more valuable when supported by subsequent long-term development. This also highlights a need for organisations to integrate training and development activities into a coherent long term strategy. Linked to this our research reveals how managers may take a direct role in the development of employees, indicating a requirement for their training and development where this occurs. Without this there is a possibility that the allocation of training and development opportunities, and relevant budgets, might become dependent on (inappropriate) subjective preferences.

\section{Limitations}

Our data inevitably convey a particular group of managers' perspectives in one country (the United Kingdom) and experiences of other employees and managers in other contexts may differ. Although based on only 26 individuals, these managers' responses provide clear insights into differing perspectives on training and development across 20 organisations. Representing professions in both public and private sector organisations, there expressed preferences for training, due to its measurability, might to some extent be a sampling artefact as participants included professions where self-initiated long-term professional training is the norm. However, given the variety of sectors and professions included, we would argue these data provide valuable insights. The use of non-probability sampling means by definition our data are not statistically representative. Yet the occurrence of data saturation suggests that for such UK managers we have captured the breadth of opinions. Inevitably our findings are dependent on the quality of our interpretation. Whilst the latter is by definition subjective, our analytic process included a constant process of checking, comparing and reflecting in our role as researchers. In addition we checked our findings face validity with our participants to ensure these findings were robustly 
grounded in the data. Consequently we believe the insights offered are both valid and useful.

\section{Concluding remarks}

In summary, our analysis highlights the importance of understanding managers' implicit theories of training and development, as they have the power within their organisations to approve or deny training and development. Whilst development appeared to be less easily justified through projected returns on investment, managers acknowledged that training and development activities are more effective if combined and thus fundamentally interlinked processes. In particular, training was understood to yield the best return in terms of sustainability of learning if supported thereafter by pertinent development activities. Although there is some research that, for instance, investigates the transfer climate for training (Tracey et al., 1995; Bates and Khasawneh, 2005; Burke and Hutchins, 2007), the perceived value of combined processes where development is used to support the transfer and further consolidation of learning achieved in training, is less well understood. Future studies might initially take a formative, rather than summative approach, using mixed methods approaches to inform our understanding as there is little or no extant theory to guide research and practice for linked processes. Investigation of the success factors for such process is important (Skinner, 2004) particularly at the present time, where due to the current economic climate organisations are cutting back rather than investing in training (Kingston, 2009).

Our research highlights the importance of management support to the success of development activities. Whilst it was acknowledged that employees have to be motivated for development to be effective, development was not perceived as an entirely self-initiated and self-managed process. Managers were clear that meaningful development could not take place within organisations unless it was supported. Accordingly, we propose that future research should consider both the role of the manager and the social context as well as individual motivational factors with particular reference to how these facilitate development. Building from this argument, there is then also a need to consider managers more actively in the fostering of an 
overall organisational culture that supports learning through training and development, in a more strategic HR context. Whilst research in the domain has been lamented as atheoretical (Tannenbaum and Yukl, 1992), the findings of our research highlight a need for theory building aspects that focus upon how training and development are interlinked, rather than concentrating on the distinctions between activities, and the role of managers both in decision making and facilitating transfer of learning.

\section{References}

Antonacopolou, E.P (2001), “The paradoxical nature of the relationship between training and learning”, Journal of Management Studies, Vol. 38, pp. 327-349.

Argyris, C. and Schön, D. (1978), “Organizational learning: A theory of action in perspective”, Reading, Mass, Addison Wesley.

Arthur, W.A., Bennett, W., Edens, P.A. and Bell, S. T. (2003), "Effectiveness of training in organizations: A meta-analysis of design and evaluation features", Journal of Applied Psychology, Vol. 88, pp. 234-245.

Arthur, B.A. and Rousseau, D. M (1996), “The Boundaryless Career: A New Employment Principle for a New Organizational Era", Oxford, U.K.: University Press.

Atwater, L. E. and Yammarino, F. J. (1992), "Does Self-Other Agreement of Leadership Perceptions Moderate the Validity of Leadership and Performance Predictions?", Personnel Psychology, Vol. 45, pp. 141-163.

Bates, R. and Khasawneh, S. (2005). Organizational Learning Culture, Learning Transfer Climate and Perceived Innovation in Jordanian Organizations, International Journal of Training and Development, Vol. 9 No. 2, pp. 96-109

Birdi, K., Allan C. and Warr, P. (1997), "Correlates and Perceived Outcomes of Four Types of Employee Development Activity", Journal of Applied Psychology, Vol. pp. $82,845-857$.

Boudreau, J.W. and Ramstad, P.M (1998), "Measuring intellectual capital: learning from financial history", Human Resource Management, Vol. 36, pp. 343-356. 
Boyatzis, R.E. (1982), “The competent manager: A model for effective performance. New York, U.S.: Wiley.

Boyatzis, R.E. (2008), "Competencies in the $21^{\text {st }}$ Century", Journal of Management Development, Vol. 27, pp. 5-12.

Brown, K. and Gerhardt, M.W. (2002), "Formative Evaluation: An Integrative Practice Model and Case Study”, Personnel Psychology, Vol. 55, pp. 951 - 983.

Brown, V. and Clarke, V. (2006), "Using thematic analysis in psychology", Qualitative research in Psychology, Vol. 3, pp. 77-101.

Buckley, R. and Caple, J. (2007), "The Theory \& Practice of Training” (5 ${ }^{\text {th }}$ ed.). London, Kogan Page.

Burke, L.A. and Hutchins, H.M. (2007), "Training transfer: an integrative literature review," Human Resource Development Review, Vol. 6 No. 3, pp. 263-296

Cannell, M. (2004), “Training: a short history”, London, Chartered Institute of Personnel and Development. Available on-line at http://www.cipd.co.uk/subjects/training/general/thistory.htm?IsSrchRes=1; accessed $29^{\text {th }}$ September 2009.

Chartered Institute of Personnel and Development [CIPD] (2007), "Learning and Training", Annual Survey Report, published on line by CIPD at http://www.cipd.co.uk/NR/rdonlyres/EB18FA28-BD40-4D47-81B9660034D280C1/0/learndevsr.pdf, accessed $6^{\text {th }}$ April 2009.

Cohen, D (2007) The very separate worlds of academic and practitioner publications in Human Resource Management: Reasons for the divide and concrete solutions for bridging the gap Academy of Management Journal 50.5 1013-1019

Colquitt, J. A., LePine, J. A and Noe, R.A. (2000), “Toward an integrative theory of training motivation: A meta-analytic path of 20 years of research", Journal of Applied Psychology, Vol 85, pp. 678-707.

Cook, M. (2009). Personnel Selection: Adding Value through People. London, Wiley Blackwell.

Davenport, T. O. (1999), "Human Capital: What is it and why people invest in it", San Francisco, Jossey Bass. 
Dillman, D.A. (2009). Mail and Internet Surveys: The Tailored Design Method. $\left(3^{\text {rd }}\right.$ Edn.), Hobeken, NJ: Wiley.

Fitzgerald, W. (1992), “Training vs. development”, Training and Development, 84, 81-82.

Goldstein, I. L. (1993), “Training in organisations”, Pacific Grove, CA, U.S.: Brooks Cole.

Goldstein, I.L and Gilliam, P. (1994), “Training system issues in the Year 2000”, In Schneier, C.E., Russell, C.J., Beatty, R.W. and Baird, L. S. (eds.), The training and development sourcebook, Human Resource Development Press, Amherst, U.S.

Guest, G., Bunce, A. and Johnson, L. (2006), "How many interviews are enough?" Field Methods, Vol. 18, 59-82.

Hall, D. T. (1996), "Protean Careers of the 21st Century", Academy of Management Executive $10,8-16$.

Hall, D. T. and Mirvis, P. (1995), “The new career contract: Developing the whole person at midlife and beyond", Journal of Vocational Behavior, Vol. 47, pp. 269-289.

Harrison, R. (2005), “Learning and Development”, London, Chartered Institute of Personnel and Development.

Horner, L. and Jones, A. (2003), “Great Expectations. Understanding the motivation of young workers”, London, U.K.: The Work Foundation.

Ilgen, D. R., Fisher, C. D. and Taylor, M.S. (1979), “Consequences of Individual Feedback on Behaviour in Organisations", Journal of Applied Psychology, Vol. 64, pp. 349-371.

Jones, R. G. and Whitmore, M. D. (1995), "Evaluating Developmental Assessment Centers as Interventions", Personnel Psychology, 48, 377-388.

King, N (2004), "Using templates in the thematic analysis of text", In C. Cassell and G. Symon (Eds.), Essential Guide to Qualitative Methods in Organizational Research. London, U.K.: Sage. 
Kingston, P. (2009), "Staff training: chill wind hits training budgets", guardian.co.uk, accessed at http://www.guardian.co.uk/education/2009/jan/27/staff-training-workcareers on 3rd August 2009

Kirkpatrick, D. L. (1959), “Techniques for evaluating training programs”, Journal of American Society of Training and Development, 13, pp. 3-9.

Kluger, A. N. and DeNisi, A. (1996), "The Effects of Feedback Interventions on Performance: A Historical review, a Meta-analysis and a Preliminary Feedback Intervention Theory", Psychological Bulletin, 119, pp. 254-284.

Kraiger, K., Ford, K and Salas, E. (1993), “Application of Cognitive, Skill-based, and Affective Theories of Learning Outcomes to New Methods of Training Evaluation", Journal of Applied Psychology, Vol. 78, pp. 311-328.

Laird, D. (1985), “Approaches to Training and Development”, New York, U.S.: Wiley.

Maurer, T. J., Mitchell, D.R.D and Barbeite, F.G. (2002a), "Predictors of attitudes toward a 360-degree feedback system and involvement in post-feedback management development activity", Journal of Occupational and Organizational Psychology, Vol. 75, pp. 87-107.

Maurer, T. J., Weiss, E. M. and Barbeite, F.G. (2003), “A Model of Involvement in Work-Related Learning and Development Activity: The Effects of Individual, Situational, Motivational, and Age Variables", Journal of Applied Psychology, Vol. 88 No. 4, pp. 707-724.

Maurer, T. J., Pierce, H. R. and Shore, L.M. (2002b), "Perceived beneficiary of employee development activity: A three-dimensional social exchange model", Academy of Management Review, 27, pp. 432-444.

Maurer, T. J. and Tarulli, B. A. (1994), "Investigation of Perceived Environment, Perceived Outcome, and Person Variables in Relationship to Voluntary Development Activity by Employees", Journal of Applied Psychology, Vol. 79, pp. 3-14.

McDowall, A. and Fletcher, C (2004). Management Development from an Organisational Justice Perspective. Personnel Review, 33, pp. 8-30.

McDowall, A. and Mabey, C. (2008), "Developing a framework for assessing effective development activities, Personnel Review, Vol. 37 No. 6, 629-646 
Naish, R. and Birdi, K. (2001), "Evaluation of the Behavioural, Affective and Financial Outcomes of Sixteen Management Development Centres", Proceedings of the Occupational Psychology Division and Section British Psychological Society Annual Conference, Winchester January 2001.

Patton, M.Q. (2002), "Qualitative research and evaluation methods ( $3^{\text {rd }}$ edition)”, London, U.K.: Sage.

Phillips, J.I. (2003), "Return on investment in training and performance improvement programs", Butterworth-Heinemann.

Poland, B.D. 2002, “Transcription quality. In Gubrium, J.F. and Holstein, J.A., editors, Handbook of interview research: context and method", Sage, pp. 629-49. Reid, M. A. and Barrington, H. (1994), “Training interventions”, London, U.K.: Institute of Personnel and Development.

Rice, L. N. and Greenberg, L. S. (1984), "Patterns of Change”, New York, Guildford. Rouiller, J. Z. and Goldstein, I. L. (1993), “The relationship between organizational transfer climate and positive transfer of training", Human Resource Development Quarterly, 4, pp. 377-390.

Rousseau, D. (1995), "Psychological Contracts in Organizations: understanding written and unwritten agreements", London: Sage Publications.

Rowold, J. and Kauffeld, S. (2009), "Effects of career-related continuous learning on competencies, Personnel Review, Vol. 38 No. 1, 90-101

Salas, E. and Cannon-Bowers, J.A. (2001), "The Science of Training: A Decade of Progress", Annual Review of Psychology, Vol. 52, pp. 471-499.

Sadler-Smith, E. (2005), "Learning and Development for Managers: Perspectives from Research and Practice: Integrating Individual and Organizational Learning”, Oxford: Blackwell Publishing

Senge, P. M. (2006), "The fifth discipline: The art and practice of the learning organization", (Revised edition). New York, U.S.: Doubleday.

Silverman, D. (2000), "Doing Qualitative Research. A Practical Handbook", London, U.K. : Sage Publications. 
Skinner, D. (2004), "Evaluation and Change Management: rhetoric and reality", Human Resource Management Journal, 14, 5-20

Sloman, M. (2003), "Training in the age of the learner", London, U.K.: Chartered Institute of Personnel and Development.

Smither, W., London, M. A. and Reilly, R. R. (2005), "Does Performance Improve Following Multisource Feedback? A Theoretical Model, Meta-Analysis, and Review of Empirical Findings", Personnel Psychology, Vol. 58, pp. 33-52.

Tamkin, P., Yarnell, J., and Kerrin, M. (2002), "Kirkpatrick and Beyond: a review of training evaluation", The Institute for Employment Studies, U.K., Report Number 392.

Tannenbaum, S. I., Mathieu, J. E., Salas, E. and Cannon-Bowers, J.A. (1991), "Meeting Trainees' Expectations: The Influence of Training Fulfilment on the Development of Commitment, Self-Efficacy, and Motivation", Journal of Applied Psychology, Vol. 76, pp. 759-769.

Tannenbaum, S.I. and Yukl, G. (1992). Training and Development in Work Organizations. Annual Review of Psychology, Vol. 43, 399-441.

Thomson, A., Mabey, C., and Storey, J. (1998)", The determinants of management development: choice or circumstance", International Studies of Management and Organisation, 28, pp. 91-113.

Tracey, J. B., S. I. Tannenbaum and Kavanagh, M.J. (1995), "Applying Trained Skills on the Job: The Importance of the Work Environment", Journal of Applied Psychology, Vol. 80, pp. 239-252.

Tracey, J. B., Hinkin, J. R., Tannenbaum, S. and Mathieu, J.E. (2001), “The influence of individual characteristics and the work environment on varying levels of training outcomes", Human Resources Development Quarterly, Vol. 12, pp. 5-23.

Warr, P. (2002), “Learning and Training”, In P. Warr. (Ed.) Psychology at Work. London, U.K: Penguin Books.

Willig, C. (2001), "Introducing qualitative research in psychology", Maidenhead, U.K.: McGraw-Hill. 
Table 1: Training and Development in Contrast

\begin{tabular}{|c|c|c|}
\hline & Training & Development \\
\hline \multicolumn{3}{|c|}{ Practical differences } \\
\hline Overall aim & $\begin{array}{l}\text { Aim is to improve effectiveness in current role, typically seen as } \\
\text { provided by the organisation }\end{array}$ & $\begin{array}{l}\text { Aim is to improve longer-term effectiveness, personal element, } \\
\text { typically initiated by individual }\end{array}$ \\
\hline Focus & Performance of the task or specific job role & General individual progress, professionally and personally \\
\hline Objectives & Job specific fixed-term orientation & $\begin{array}{l}\text { Future directed, long-term, usually career related; can be aligned with } \\
\text { organisational objectives }\end{array}$ \\
\hline Time span & $\begin{array}{l}\text { Can vary greatly in length, style of delivery and content; traditionally } \\
\text { often delivered as class-room type instruction which is 'stand alone' and } \\
\text { 'one off' }\end{array}$ & $\begin{array}{l}\text { Should be on-going; even one off events such as development centres } \\
\text { should be linked in with overall development strategy }\end{array}$ \\
\hline $\begin{array}{l}\text { Role of } \\
\text { Manager }\end{array}$ & $\begin{array}{l}\text { Manager very important for supporting learning from both training and } \\
\text { developmental activities in organisations }\end{array}$ & Managerial support is also crucial in the literature on participation \\
\hline Examples & $\begin{array}{l}\text { Skills-based training (e.g. mastering new manufacturing tool), customer- } \\
\text { service training, professional training, open learning; can take place on } \\
\text { or off the job }\end{array}$ & $\begin{array}{l}\text { Diverse range of activities which can be formal or informal } \\
\text { taking place on the job or off the job }\end{array}$ \\
\hline $\begin{array}{l}\text { Theoretical } \\
\text { Underpinning }\end{array}$ & $\begin{array}{l}\text { Rooted in learning theory and cognitive psychology, } \\
\text { acknowledging interplay between individual characteristics and } \\
\text { organisational requirements. Research on training evaluation and } \\
\text { effectiveness, in particular factors that may impact on motivation }\end{array}$ & $\begin{array}{l}\text { Diverse roots, from management development and organisational } \\
\text { strategy. Ranges from managerial competence to models of factors } \\
\text { influencing participants }\end{array}$ \\
\hline Learning & Learning through instruction and skill acquisition & Learning through feedback and self-reflection \\
\hline
\end{tabular}

Page 32 of 35 
Individual

differences

and

motivation

Employee-

employer

relationship

Projected

Outcomes

Enhanced skills at the individual level and organisational benefits should result in measurable improvement in workplace performance measures

Validity

Consistent evidence that well delivered training courses result in

improvement on task performance, and that motivation predicts success
Individual differences have been considered explicitly in models explaining participation in development activities which are rooted in social psychological constructs such as social exchange theory and theory of planned behaviour

Transactional contract; onus rests on employees to acquire transferable skills for multiple careers. Constructivist perspective focussing on person-organisation and person-team as well as personjob fit

Increased self-awareness and learning, growing impetus to take charge of personal and professional development, increased

'marketability' to current and future employer; Diverse measures used such as promotions, number of training days engaged in, level of agreement between ratings, staff retention

Equivocal evidence, as research frameworks and criteria vary between studies; as development appears to refer to a wide range of activities 
Table 2: Example meaningful theme and corresponding codes from the Final Template

\begin{tabular}{|c|c|c|}
\hline First level (Meaningful theme) & Second level (Codes) & Third level (Sub-codes) \\
\hline \multirow[t]{7}{*}{$\begin{array}{l}\text { 2. Links between training and } \\
\text { development }\end{array}$} & 2.1. Intertwined functionality & $\begin{array}{l}2.1 .1 \text {. Training and development addressed } \\
\text { by same department }\end{array}$ \\
\hline & & $\begin{array}{l}\text { 2.1.2. Training and development addressed } \\
\text { by same person }\end{array}$ \\
\hline & & $\begin{array}{l}\text { 2.1.3. Managers don't think about them as } \\
\text { being different, as addressed by same } \\
\text { function }\end{array}$ \\
\hline & 2.2. Combined effectiveness & $\begin{array}{l}\text { 2.2.1. Development builds on training } \\
\text { (training has to come first) }\end{array}$ \\
\hline & & $\begin{array}{l}\text { 2.2.2. Development applies learning from } \\
\text { training course ("chewing over and } \\
\text { applying") }\end{array}$ \\
\hline & & $\begin{array}{l}\text { 2.2.3. Training without development is less } \\
\text { valuable }\end{array}$ \\
\hline & & $\begin{array}{l}\text { 2.2.4. Training can be one process that } \\
\text { feeds into development, in other words } \\
\text { training as a process, development as the } \\
\text { outcome }\end{array}$ \\
\hline
\end{tabular}

Page 34 of 35 
Table 3: New insights from the study

\begin{tabular}{|c|c|c|}
\hline Insight & Implications for research & Implications for practice \\
\hline $\begin{array}{l}\text { Training and development work best when conceptualised and } \\
\text { implemented as a linked process }\end{array}$ & $\begin{array}{l}\text { Necessity for process-driven research } \\
\text { that investigates what processes } \\
\text { contribute to the effectiveness of } \\
\text { linked activities }\end{array}$ & $\begin{array}{l}\text { Need to embed training and learning activities into } \\
\text { organisational strategy }\end{array}$ \\
\hline $\begin{array}{l}\text { Development might not necessarily be as self-led as implied } \\
\text { by the literature, some managers here purported to play a } \\
\text { pivotal role }\end{array}$ & $\begin{array}{l}\text { Research needs to address the } \\
\text { potentially differing effects of } \\
\text { mandatory and voluntary activity from } \\
\text { a systems perspective, rather than } \\
\text { the individual perspective alone }\end{array}$ & $\begin{array}{l}\text { Expectations regarding the contribution of different } \\
\text { parties to development and training processes need to } \\
\text { be made explicit and negotiated upfront }\end{array}$ \\
\hline $\begin{array}{l}\text { Managerial preference and decision making emphasises the } \\
\text { importance of a measurable return on investment }\end{array}$ & $\begin{array}{l}\text { Need for different 'metrics' to } \\
\text { determine return on investment for } \\
\text { development }\end{array}$ & $\begin{array}{l}\text { Organisations need to provide both managers and } \\
\text { employees with support and guidance for decision } \\
\text { making to ensure that employees are given adequate } \\
\text { access to all types of development and training } \\
\text { activities }\end{array}$ \\
\hline $\begin{array}{l}\text { An individual's motivation to develop is a pre-requisite for } \\
\text { development success }\end{array}$ & $\begin{array}{l}\text { Need to understand whether this } \\
\text { motivation construct may map onto } \\
\text { existing measures and constructs or } \\
\text { whether there are unique features } \\
\text { that merit different measures to } \\
\text { capture differences }\end{array}$ & $\begin{array}{l}\text { Organisations need to make active steps to understand } \\
\text { individual 'drive factors' }\end{array}$ \\
\hline
\end{tabular}

Page 35 of 35 